\title{
The Oosterschelde Storm Surge Barrier. A Test Case for Dutch Water Technology, Management and Politics
}

Citation for published version (APA):

Bijker, W. E. (2002). The Oosterschelde Storm Surge Barrier. A Test Case for Dutch Water Technology, Management and Politics. Technology and Culture, 43, 569-584. https://doi.org/10.1353/tech.2002.0104

Document status and date:

Published: 01/01/2002

DOI:

10.1353/tech.2002.0104

Document Version:

Publisher's PDF, also known as Version of record

\section{Please check the document version of this publication:}

- A submitted manuscript is the version of the article upon submission and before peer-review. There can be important differences between the submitted version and the official published version of record.

People interested in the research are advised to contact the author for the final version of the publication, or visit the DOI to the publisher's website.

- The final author version and the galley proof are versions of the publication after peer review.

- The final published version features the final layout of the paper including the volume, issue and page numbers.

Link to publication

\footnotetext{
General rights rights.

- You may freely distribute the URL identifying the publication in the public portal. please follow below link for the End User Agreement:

www.umlib.nl/taverne-license

Take down policy

If you believe that this document breaches copyright please contact us at:

repository@maastrichtuniversity.nl

providing details and we will investigate your claim.
}

Copyright and moral rights for the publications made accessible in the public portal are retained by the authors and/or other copyright owners and it is a condition of accessing publications that users recognise and abide by the legal requirements associated with these

- Users may download and print one copy of any publication from the public portal for the purpose of private study or research.

- You may not further distribute the material or use it for any profit-making activity or commercial gain

If the publication is distributed under the terms of Article $25 \mathrm{fa}$ of the Dutch Copyright Act, indicated by the "Taverne" license above, 


\title{
ESSAYS
}

\section{The Oosterschelde Storm Surge Barrier}

\author{
A Test Case for Dutch Water Technology, \\ Management, and Politics
}

\section{WIEBE E. BIJKER}

"God created the world, and the Dutch created the Netherlands." The old adage summarizes-albeit in an immodest, not to say blasphemous, waythe popular Dutch view of their relationship to water. There is some truth in it: about half the country is below sea level and would be flooded without the dikes that hold back the waters of the rivers and the sea. But the relationship is not as straightforward-humans dominating nature-as the phrase suggests. It is, for example, mediated in complex ways by science and technology. In this essay I will focus on one recent crisis in this relationship between the Dutch and the sea, the disastrous flood of 1953, and its resolution through the Delta Plan, and in particular the building of the storm surge barrier in the Oosterschelde. ${ }^{1}$

Dr. Bijker is professor of technology and society at the University of Maastricht, Faculty of Arts and Culture.

@2002 by the Society for the History of Technology. All rights reserved.

0040-165X/02/4303-0006\$8.00

1. I am grateful to Martin Reuss and John Staudenmaier for inviting me to contribute this essay. It allows me to address Dutch coastal engineering more fully than $I$ did in two previous publications, which had a primarily methodological purpose. And, in a way, it serves to fulfill an old dream. It is only because I did not want to sit in my father's classes that I studied physics rather than civil engineering, but my fascination with the water sorcerers never faded. This essay gives me an opportunity to return to this old fascination, albeit under the banner of the history of technology.

The term "water sorcerers" was coined by Den Doolaard in Het verjaagde water. This 1948 novel gives an engaging and historically accurate account of the 1945 closures of the dikes that were bombed by British planes to drive the Germans out of the polders in the southwest of the Netherlands. The novel, which inspired Samuel Florman to write his reflections on being an engineer, was translated into nine languages, and has recently been republished by the Delft University of Technology with several appendices giving additional technical and historical information. A. den Doolaard, Het verjaagde water, ed. Kees d'Angremond and Gerrit-Jan Schiereck (Delft, 2001); A. den Doolaard, Roll Back the Sea, trans. June Barrows Mussey (New York, 1948); Samuel Florman, The Existential Pleasures of Engineering (New York, 1976). 


\section{TECHNOLOGY AND CULTURE}

Technology has always played a central role in the relationship between the Dutch and the sea. From the earliest mound constructions, built to keep farm houses and outbuildings dry during the frequent floods, to windmills and steam-driven pumping stations the Dutch have actively tried to control their environment with technology. ${ }^{2}$ But the science and technology needed for the Delta Plan, and especially the research and high-tech solu-

JULY

2002

VOL. 43 tions used in the construction of the Oosterschelde barrier, constituted a radical departure from centuries-old traditions.

During the nineteenth century and the first half of the twentieth century, relations between government agencies and private construction companies involved in the building and maintenance of dikes, locks, sluices, and other water control structures were subject to routines and procedures that provided for adequate checks and balances. The central government agency responsible for the water control system, the Rijkswaterstaat, typically designed harbors, dikes, sluices, bridges, and so on, and then contracted the construction out to private conpanies. These companies submitted bids, sometimes joining together in consortia when the project was big and complicated, and the company or consortium with the lowest bid received the contract. Once construction began, the Rijkswaterstaat monitored the process. This style of management was radically changed for the Oosterschelde project. ${ }^{3}$

The earliest forms of democracy in the Netherlands were related to dike and sluice maintenance and management. From the twelfth century onward, specialized water boards (waterschappen), supervised by elected councils, assumed responsibility for local dikes and sluices. These boards constituted a highly decentralized form of democracy in which all landowners had voting rights, with the weight of each vote depending on the extent of the landowner's property. The Delta Plan can be seen as a fundamental change in the balance between local and national water politics.

The Delta Plan, and particularly the Oosterschelde project, precipitated a crisis involving three aspects of the relationship between the Dutch and the sea: technology, management, and political culture. I will argue, however, that in the end that crisis only reinforced the basic characteristics of this relationship.

\section{The 1953 Flood}

On 31 January 1953, a Saturday night, ebb tide did not bring a lowering of the water level as it always does. Then, as the tide began to come in, a

2. See Petra van Dam's, Ane Kaijser's, and William TeBrake's articles elsewhere in this special issue for accounts of early sluice technology, the implications of windmill development for political institutions, and drainage technology.

3. On the history of the Rijkswaterstaat, see Harry Lintsen's essay elsewhere in this issue. 


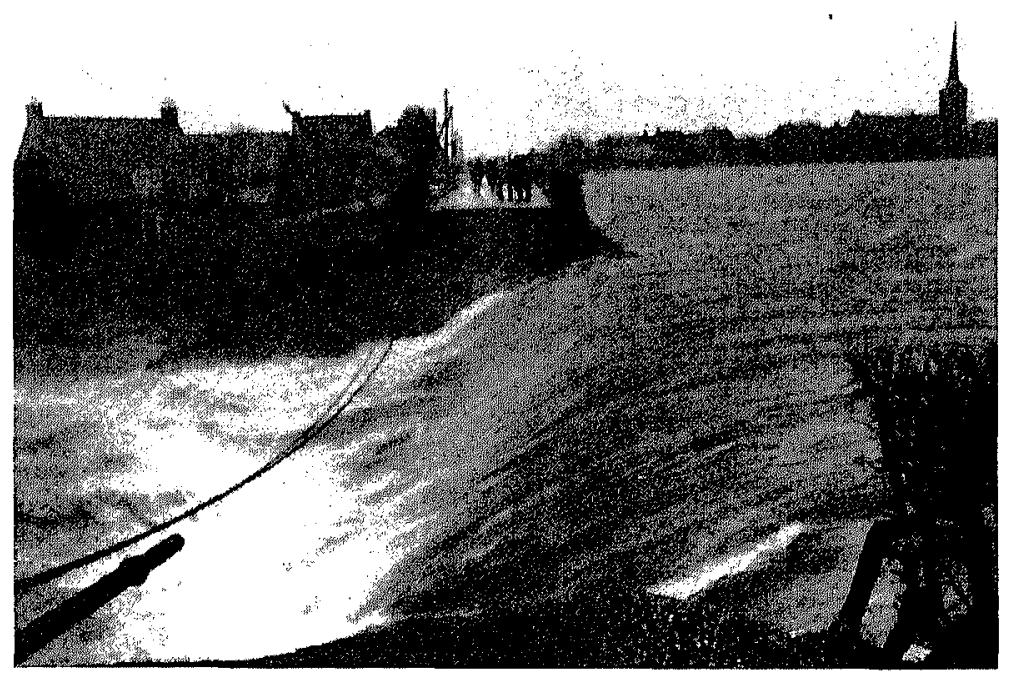

FIG. 1 A broken dike, 1 February 1953. (De Ramp: Nationale uitgave [Amsterdam, 1953].)

storm pushed the water to higher than normal levels. In the early morning of 1 February the sea reached the top of the dikes in Zeeland, at the southern end of the Dutch coast. Waves started to nibble at the back slopes of the dikes, which are not armored by stones, undermining them from the rear, and eventually the dikes broke. Quickly the breaches were scoured out by the seawater rushing into the polders, several meters below sea level (fig. 1).

Analyses later showed that it had been neither a particularly high spring tide nor an exceptionally strong storm. It had, however, been a long-lasting storm, and, crucially, one that had changed direction in a very particular manner at exactly the wrong moment. A northerly wind had first pushed the flood wave along the British coast toward the narrow channel between England and the Netherlands. Just as this tidal wave reached the Dutch coast the wind veered to the west, sending the water more forcefully against the coast. ${ }^{4}$

It took several days before the extent of the disaster became clear to the rest of the Netherlands, as communications with the affected areas had broken down and there were no helicopters and but few aircraft. In one week, 1,835 people drowned. More than 750,000 inhabitants were affected, and 200,000 hectares of land were inundated (fig. 2). The effects were traumatic, both for individuals and for the Netherlands as a country. This became particularly clear in the 1970s, when political discussions about water management were cast in terms of safety versus ecology.

4. Rijkswaterstaat and Koninklijk Nederlands Meterologisch Instituut, Verslag over de stormvloed van 1953 (The Hague, 1961). 
TECHNOLOGY AND CULTURE

JULY

2002

VOL. 43

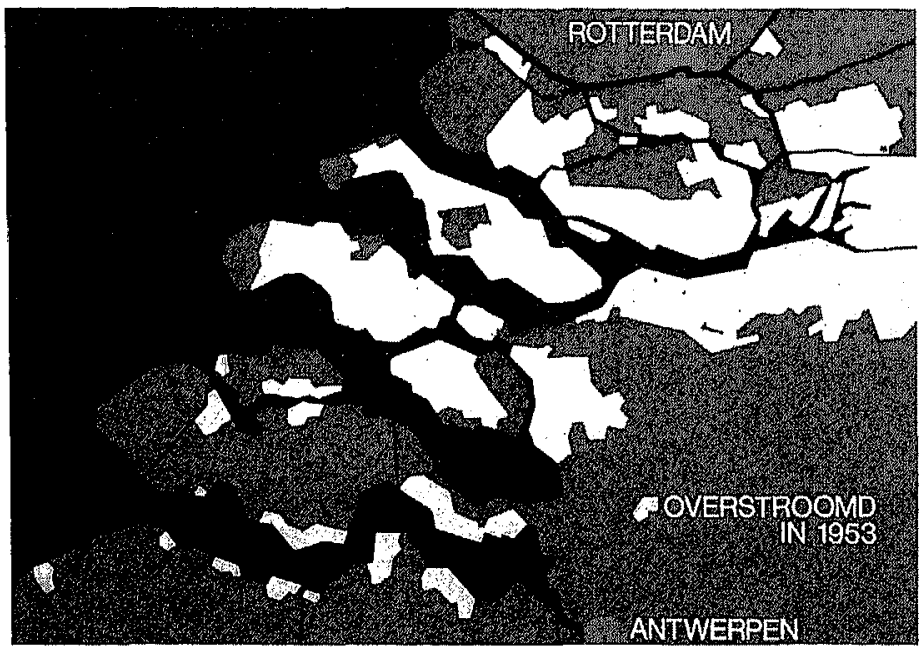

FIG. 2 Zeeland, in the southeast corner of the Netherlands. The white parts were flooded in 1953. (Courtesy Rijkswaterstaat Archief, the Hague.)

The whole gamut of technologies that had been developed during centuries of keeping the sea out were employed to reclaim the lost land. ${ }^{5}$ Time was a crucial factor. Tidal currents quickly widen any breach in a dike. The largest breach in the 1953 disaster was 100 meters wide and 15 meters deep on 1 February, but within a few months it had grown to 200 meters by 20 meters. If the breaches were not closed before the next winter season, the damage might become irreversible. Time was critical on the scale of minutes as well as months: currents rage at their fastest where breaches are at their smallest, so the right moment to close off a breach in a dike is during the few minutes of slack water.

For centuries the key material used to strengthen and repair dikes has been sand in jute bags. On the night of I February 1953, sandbags were made available from emergency depots and played a crucial role in batthing the flood. Sand is readily available and very heavy, but unpacked sand would immediately be swept away by the water-hence the jute sacks. Only with the enclosure of the Zuider Zee in the 1920s did keileem, a heavy clay from glacial moraines, come to be used to build dikes so large

5. Johan van Veen, a Rijkswaterstaat engineer from the 1920 s to the 1950s, gives a historical review of early Dutch coastal engineering technologies in Dredge, Drain, Reclaim: The Art of a Nation, 5th ed. (The Hague, 1962). Before 1940 van Veen developed several plans to close tidal inlets in Zeeland, and these played an important role after 1953. Since 1937 he had warned of the deplorable state of dike maintenance, to no avail. He appended a critical analysis of the 1953 disaster-under the pseudonym "Cassandra" - to the fifth and last edition of his book. 
that sandbags could no longer serve as the feasible core and beginning of a dike.

In 1953, as in the centuries before, human power did most of the work, in combination with the skills needed to move the sandbags by human chains and place them where they would do the most good. Muscle power was the only energy source distributed widely enough through the Dutch coastal area to act adequately at short notice. Dredges, tugs, ships, and cranes would eventually be called in to close the breaches in the dikes, but on that February night everything depended on human hands.

An armored foundation is necessary to build a dike in a gap where tidal currents flow. For centuries fascine mattresses consisting of a net structure about 50 centimeters thick, 100 meters long, and 20 meters wide have been used for this purpose. A series of such mattresses lowered onto the seabed provides a foundation for the dike. Until the 1970s the dikes in the Netherlands were built on mattresses woven by hand from branches of willow trees or similar material. ${ }^{6}$ The mattresses were fabricated on land, then towed out to sea and sunk by carefully dumping quarry stone on them. This was done by hand, to ensure that the mattress was lowered gradually and in a controlled manner into the right position (fig. 3).

These basic technologies were used to good effect in 1953. In the decades that followed, however, radical innovations were developed and new high-tech tools created for building dikes, sluices, and storm barriers. When one looks carefully, though, the same basic techniques (usually excepting manual labor) are still deployed in all hydrological projects.

\section{Early Water Politics}

There are such striking similarities between early water politics and the present political culture in the Netherlands that it is illuminating to briefly review the history of the political systems that have governed Dutch water management since the Middle Ages. ${ }^{7}$ Around the beginning of the previous millennium the first collective organizations developed to maintain dikes and sluices. In the twelfth century the water boards were established, the first democratic institutions in the Netherlands, which still exist today. These statutory organizations were (and still are) governed by councils elected by landowners whose voting rights correspond to the size of their

6. This is a Dutch technique that was transferred in the twentieth century to other countries, where bamboo was often used in place of willow branches. Without this mattress technique dikes have to be built on a bed of gravel built up of several layers, each using larger stones than the one below it, which is much more difficult to construct.

7. See, in particular, Frans van Waarden, notes from a lecture titled "Truth in the Stereotypes? Or Hydraulics and Dutch Political Culture and Institutions," Wassenaar, 1999, copy in the author's possession. 
TECHNOLOGY AND CULTURE

JULY

2002

VOL. 43

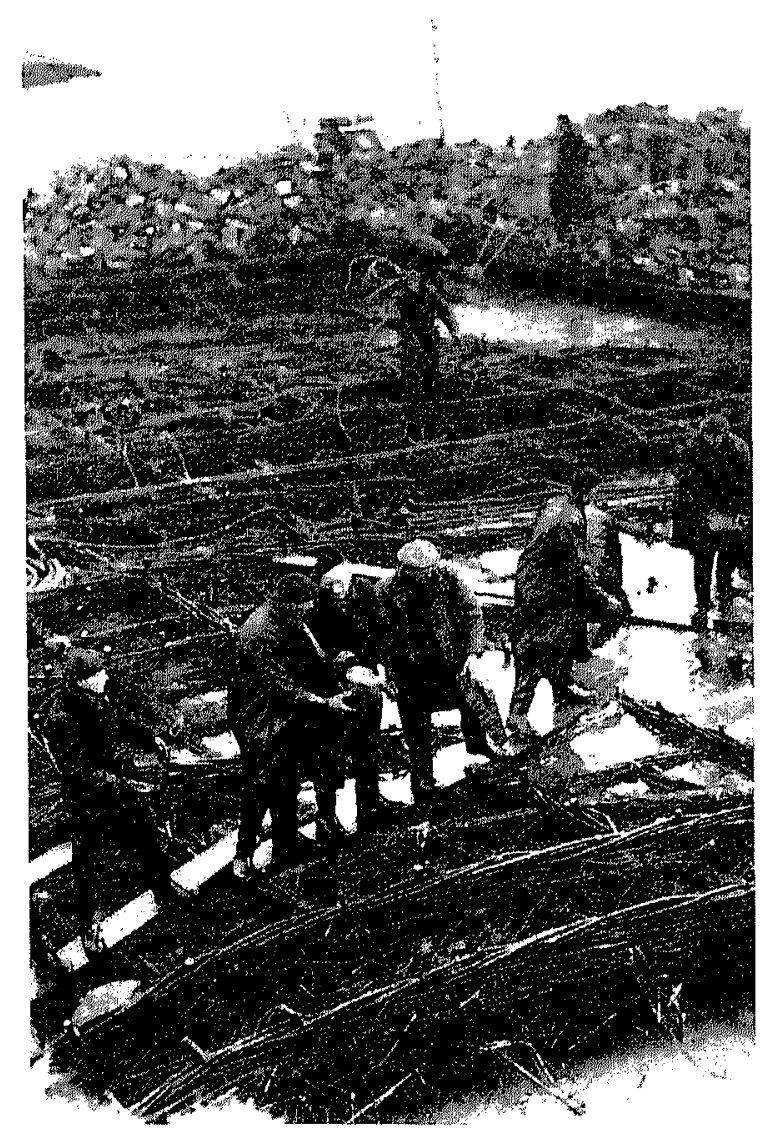

FIG. 3 A willow mattress being sunk. (Kees Slager, De Ramp: Een reconstructie [Goes, 1992].)

properties. The duties of the boards included such communal tasks as drainage, dike maintenance, and sluice management. They had the power to levy taxes, and some acquired additional legislative, judicial, and executive powers. A few times each year they conducted inspections, and when parts of the hydraulic infrastructure were found to be out of order those responsible were severely fined. Only during the eighteenth century did a more centralized system of oversight gradually develop, and in 1798 the first national agency, the Rijkswaterstaat, was established. ${ }^{8}$

Dutch political culture still exhibits several characteristics that can be traced back to this early history of water politics. First, there is a certain trust

8. For more details on early Dutch politics and water management, see Kaijser's and TeBrake's articles elsewhere in this issue. 
Bijker | The Oosterschelde Storm Surge Barrier

in technical solutions and in technocracy-perhaps not as much as in France, but more, for example, than is found in Germany. Indeed, close links exist between policy makers and scientists (including social scientists) and engineers. A sense of vulnerability, because of the centuries-long threat from high water, is compensated for by a capacity to react swiftly to crises. In reaction to a crisis, Dutch politics will often take a pragmatic approach to find ad hoc and flexible solutions, even when this means flexibly interpreting regulations. ${ }^{9}$ The Dutch have a long tradition of planning and actively shaping their environment. This applies not only to the physical landscape of the Netherlands but also to society; Dutch political culture displays a general belief in the malleability of society. Finally, the political culture of the Netherlands is distinctly consensual and oriented toward cooperation and compromise. ${ }^{10}$ This is not to say that there are no opposing interests or conflicts. But in the end the Dutch need to cooperate with each other, under penalty of being flooded. ${ }^{11}$ In the 1950 s the restoration of the prewar political culture strengthened many of these characteristics. In this essay I will argue that this strengthening process culminated in the Delta Plan that was adopted after the 1953 disaster. However, during the Oosterschelde enclosure, the final step in the Delta Plan, the process produced a crisis.

Since the end of the nineteenth century the construction of dikes and other large infrastructural works had been organized in a straightforward manner: the Rijkswaterstaat designed projects and then contracted with private companies to carry them out under the supervision of Rijkswaterstaat engineers. The distinct duties and responsibilities of Rijkswaterstaat and contractors were clear, and the dividing line between the two was unambiguous. Numerous stories convey the almost sporting relationship between Rijkswaterstaat inspectors and the chief engineers of the dredging companies, both trying to get the better of the contract. ${ }^{12}$

9. Examples that do not concern water are the contemporary policies related to abortion, prostitution, and drugs.

10. For a discussion of the implications of this characteristic for housing politics after World War II, see Wiebe E. Bijker and Karin Bijsterveld, "Women Walking through Plans: Technology, Democracy and Gender Identity," Technology and Culture 41 (2000): 485-515.

11. An example of such pragmatic cooperation-and rule stretching-comes from the final days of closing the breaches made in the dikes in 1953. It was the beginning of autumn and time was running out; if the gaps were not closed quickly the autumn storms would scour them out beyond repair. The engineers of the construction company wanted to make the final move on a Sunday, when the tidal currents would be at their weakest. The workers from this region of very strict Calvinists initially refused, because that would be breaking the Sabbath. After long talks, and when they recognized the hydrological necessity, they decided to cooperate-but only on condition that they not be paid. Eco W. Bijker, interview by author, Maassluis, 29 June 2001. Eco Bijker, my father, was one of the young engineers involved in the repair work; he later became deputy director of the Delft Hydraulics Laboratory and professor of coastal engineering at the Delft University of Technology.

12. Although the distinction between the Rijkswaterstaat and contractors was clear- 
TECHNOLOGY AND CULTURE

This transparent relationship had crystallized after the failure of Rijkswaterstaat to manage the design and construction of the Rotterdamse Waterweg (1857-77), connecting Rotterdam to the sea at Hoek van Holland. The history of the enclosure of the Zuider Zee, the inland sea east of Amsterdam, in the 1920s and 1930s added two important elements to the set of instruments that related the Rijkswaterstaat to contracting compa-

JULY

2002

VOL. 43 nies. ${ }^{13}$ The first was the creation of temporary consortia, lasting for the duration of a project, large (and rich) enough to carry the risk of the project. Four of the largest Dutch dredging and building companies joined forces and established the consortium Maatschappij tot uitvoering der Zuiderzeewerken (MUZ) as a limited liability company for the duration of the Zuider Zee project. The second innovation, closely related, was the use of the raamcontract, or frame contract. ${ }^{14}$ In a frame contract the state agency grants the construction of the whole project to the building consortium without specifying the details of the various individual structures. These structures, which together constitute the whole project, are then specified in separate contracts. The private companies thus receive assurances of their long-term involvement, which they need to make the necessary technological investments, and the state agency is still able to specify the particulars of the separate subprojects, which is necessary if it is to exercise detailed oversight. The frame contract for the Zuider Zee project also specified that the contracting consortium would take all of the first 6 percent of profit or loss, while losses or profits exceeding that amount would be shared with the state.

This combination of a legal framework and a culture of competitive collaboration between engineers of the Rijkswaterstaat and the private companies formed the starting point of the Delta Plan works, and indeed culminated during the first phase. But, in concurrence with the crisis in the political culture, the balance of power in this relationship shifted radically during the Oosterschelde project.

cut, everyone also realized that they needed each other. Additionally, all civil engineers were trained in the same school-the Delft University of Technology-and many who worked on opposite sides of these construction projects had been classmates in earlier times.

13. The Zuider Zee project presents a discontinuity in the history of the Rijkswaterstaat. Instead of granting the Rijkswaterstaat oversight of this large national project, a separate Zuider Zee agency was established and given responsibility for its management. See D. M. Ligtermoet and H. De Visch Eybergen, Uitvoering en uitbesteding: Ontwikkelingen in de organisatie van waterbouwkundige werken bij de Rijkswaterstaat, vol. 52 (The Hague, 1990).

14. The term raamcontract was not used in the 1930s. The character of the contract used then, however, is the same as the one used during the Delta Plan, when the label raamcontract was introduced. See Ligtermoet and Eybergen. 


\section{The Delta Plan}

Three weeks after the 1953 flood, a governmental committee was formed. One week later the committee put forward an interim version of the Delta Plan that called for closure of all tidal outlets except the most northerly and southerly ones, connecting Rotterdam and Antwerp to the North Sea. ${ }^{15}$ As could be expected from the Dutch political culture-swiftly reacting to a crisis with pragmatic solutions supported by a broad consensus-the implementation of the Delta Plan started even before proper political procedures had been completed. In August 1955 the Delta Project unofficially began with the building of two working harbors. On 1 May 1956 a new department within the Rijkswaterstaat that would be responsible for carrying out the Delta Plan was established. Only in November 1957 was the Delta Law debated and adopted, by a great majority, in parliament, to take effect on 8 May 1958. Formal decisions ran almost three years behind material decisions.

When the Delta Law was adopted, some of the planned closures were beyond the technical capabilities of the day. The Rijkswaterstaat engineers used the phrase "Delta school" to stress that in the course of the first phases of the Delta Plan the knowledge, skills, and technologies needed to make the most ambitious closures in the last phase possible would have to be acquired. One aspect of present Dutch hydrological practice came to fruition during the Delta Plan: the integration of scientific research and technological design. This development culminated in the Oosterschelde enclosure, but crucial first steps were made in the first phases, and indeed during the Zuider Zee enclosure. ${ }^{16}$

The first example of the integration of scientific research with hydraulic engineering dates from the 1920 s. The physicist Hendrik A. Lorentz was asked to make mathematical predictions about the tidal effects caused by a closure of the Zuider Zee. Empirical research using scale models began in the 1930s and intensified following the war. The Delft Hydraulics Laboratory, center of this modeling research, received important financial support under the Marshall Plan. Scale models developed there played a crucial role in the closure of the last breaches of the 1953 flood. The closure at Zierikzee, for example, was carried out many times in the labo-

15. The name "Delta Plan" was invented by the director general of the Rijkswaterstaat, A. G. Maris, renowned for his inventiveness in coining new words for new concepts. H. A. Ferguson, Delta-Visie: Een terugblik op 40 jaar natte waterbouw in ZuidwestNederland, vol. 49 (The Hague, 1988). It acquired such a magic ring of urgency, nationwide support, and effectiveness that decades later politicians could propose a "Delta Plan" for art restoration or a "Delta Plan" for restoring the safety of river dikes.

16. For an internal history of Dutch coastal engineering, see Eco W. Bijker, "History and Heritage in Coastal Engineering in the Netherlands," in History and Heritage of Coastal Engineering, ed. Nicholas C. Kraus (New York, 1996), 390-412. 


\section{TECHNOLOGY AND CULTURE}

ratory. ${ }^{17}$ There researchers, using springs to measure tidal forces, held the cables and played the winches holding the last caisson to be eased into the gap by the last remnants of high tide. ${ }^{18}$ (If it was to be finished before the ebb tide gained force, the operation had to commence while the flood was still strong.) The day came for the breach to be closed, and the young engineers who had practiced in the laboratory stood on deck behind the older

JULY

2002

VOL. 43 experienced workmen. When one of the cables snapped and control of the caisson was about to be lost, they were able to intervene because they had seen that snapping rope a dozen times in the laboratory model and had elaborated a scenario to save the caisson. With a series of unusual commands that took advantage of the queer characteristics of the currents they had identified in the lab, the last caisson was eased down into the final gap during the crucial few minutes of slack water. The breach was closed. ${ }^{19}$

During subsequent stages in the Delta school-from the closure of the Veerse Gat with caissons (1961), to the closure of the Haringvliet with a large system of discharge sluices (1971), to the closure of the Brouwershavense Gat in the Grevelingen with a combination of caissons and blocks of concrete dumped by a cableway (1972)-new technologies developed hand in hand with further scientific research. ${ }^{20}$ Eventually only the last and most difficult closure remained: the Oosterschelde, 8 kilometers wide at the opening, 20 to 40 meters deep, with 1.1 billion cubic meters of water moving in and out at each tide, four times a day.

A site was selected for the dam that made use of two large sandbars in the mouth of the Oosterschelde. The parts of the dam that would extend over the sandbars posed only minor problems, leaving three deep gaps to be closed. In 1971 it was decided to close these using the technique that had been employed in the Brouwershavense Gat: a huge cableway to drop the large concrete blocks that would form the core of the dike with great preci-

17. This was done with caissons-except that, since no sophisticated caissons were available, old barges were used; these were, quite spectacularly, sunk with dynamite.

18. For a more general discussion of the use of modeling in science and technology, using the same case of Dutch hydraulic coastal models, see Bruno Latour, Science in Action: How to Follow Scientists and Engineers Through Society (Cambridge, Mass., 1987).

19. One of these young engineers was my father, Eco W. Bijker. Model research is no guarantee of success, however. For one thing, it depends on whether you have modeled all relevant aspects. Though the Zierikzee closure first seemed a success, a few days later the caissons started to shift. Since the Rijkswaterstaat and the building companies had not wanted to lose time laying a fascine mattress foundation, the ground was too slippery and the caissons were pushed out of the gap.

20. I do not list the extra storm barriers, dikes, and locks that were built at the inland side of the large tidal basins. These are necessary to control the water level while allowing for discharge of the Maas and the Rhine and ship traffic. See Ferguson, Delta-Visie, and Dialoog met de Noordzee: 2000 jaar Deltawerken (Hippolytushoef, 1991); R. Antonisse, De kroon op het Deltaplan: Stornwloedkering Oosterschelde-Het grootste waterbouwproject aller tijden, rev. ed. (Amsterdam, 1986). 


\section{Bijker | The Oosterschelde Storm Surge Barrier}

sion from a height of some 30 meters. Three independent cableways were to be constructed for the three gaps. Twelve pylons were to be built, at a cost of 17.5 million guilders, each designed for the conditions at its position in the mouth, the tallest reaching some 80 meters skyward. The last pylon was to be placed in July 1974 .

But then the nationwide support that the Delta Plan had received in the 1950s started to wear thin. The special quality of the tidal ecology of the Oosterschelde was valued more than before: the polluted waters of the Rhine and Maas threatened to transform their closed estuaries from transparent lakes into huge sinks, and the butter and wheat "mountains" in the European Community diminished the importance of providing freshwater to benefit agriculture, since food production did not seem to be pressing a problem as it had been immediately after World War II. ${ }^{21}$ Other societal changes in the 1970s affected the project as well. As happened with so many other political institutions in the Netherlands, the Rijkswaterstaat's authority was challenged. During the general elections in 1972 the Oosterschelde closure became a political issue, and an alternative plan, to leave the Oosterschelde open and increase the height of its 150 kilometers of dikes, was proposed.

The new government, now including the social-democratic and leftist liberal parties, decided to investigate the possibility. A commission was formed in August 1973, and in February 1974 it produced a report recommending that a porous flood barrier be built in the mouth of the Oosterschelde, consisting of a dam of concrete blocks, that would allow seawater to pass through but reduce the tidal difference in the Oosterschelde basin by some 50 percent.

The commission's report played a crucial role in opening up the discussion, although it was criticized from all directions. Ecologists argued that the commission had not seriously investigated the "null option" to leave the Oosterschelde open. Several other groups concluded that Zeeland was left unprotected against the sea for a much longer period than was promised in the Delta Law, and most engineers criticized the plan for being technically impossible. ${ }^{22}$ Whatever the report's technical merits and shortcomings, the option of a half-open Oosterschelde was now on the agenda. The debate split the Netherlands completely, and the traumatic experience of the 1953 disaster only made the controversy more bitter. The consensual political culture of the Dutch broke down, with fault lines running though all parts of society, from government and parliament through the commu-

21. For a comprehensive account, with special attention to the increasing role of environmentalists and ecological scientists, see Cornelis Disco, "Remaking 'Nature': The Ecological Turn in Dutch Water Management," Science, Technology and Hunzan Values 27, no. 2 (2002): 206-35.

22. For one thing, the gaps in the dam would quickly fill up with cockles and sediments. 


\section{TECHNOLOGY AND CULTURE}

nity of engineers to provincial and local administrative centers and down to the level of individual families. ${ }^{23}$

\section{The Oosterschelde Barrier}

JULY

2002

VOL. 43

In 1974, with a governmental crisis threatening, parliament reluctantly accepted a compromise: to partly close the Oosterschelde with a storm barrier caisson dam-a dam consisting of caissons that are normally open but close when a storm approaches. Three additional conditions were set: (1) the plan should be technically sound, (2) the barrier should be finished not later than 1985, and (3) the extra costs, as compared to a complete closure, should not exceed twenty billion guilders. A countermotion to continue with a complete closure was rejected, 75 votes to 67 . Those who favored closure called this "a purely political decision." 24 Quickly it became clear that the political compromise was technically impossible. But at the same time, popular mistrust of the Rijkswaterstaat had reached its height. Since this agency had always been in favor of carrying out the original Delta Plan, including the complete closure of the Oosterschelde, the parliamentary decision was viewed by friend and foe alike as a slap in the face of the Rijkswaterstaat engineers. H. A. Ferguson, director of the Deltadienst, the department within the Rijkswaterstaat that carried out the Delta Plan, realized that his department was-at least temporarily-sidetracked. The people rejoiced in seeing the Rijkswaterstaat brought to its knees. It was a political drama. ${ }^{25}$

Then the dredging companies stepped in, and in a new way. ${ }^{26}$ They were given the contract to codesign the new barrier, an unprecedented level of involvement that further blurred the boundary between the state and private contractors. This process had begun with the frame contracts, but never before had the construction companies been so centrally involved in designing a whole project. A single integrated project team was established comprising engineers of four building companies, the Delft Hydraulics Laboratories, and the Rijkswaterstaat. The team started scientific modeling research into several alternative designs.

Model research had been accepted by the building companies since its

23. In my case: father still gave priority to safety and thus preferred a complete closure; sons, young engineering students in Delft, sided with the environmentalists and advocated an open Oosterschelde; and mother mediated to keep the family together.

24. This is of course a rather trivial label for a decision taken in parliament, but what they meant was a technically uninformed decision.

25. H. A. Ferguson, interview by author, Voorburg, 15 March 1993, I did this interview with Eduard Aibar and Rob Hagendijk.

26. Age J. Hoekstra, one of the directors of the large dredging and construction company Volker, commented on the plan to create a half-open Oosterschelde: "As a civil engineer I thought it a silly idea, but as a contractor I saw a great project down the road." Interview by author (with Rob Hagendijk), Oostvoorne, 31 March 1998. 


\section{Bijker | The Oosterschelde Storm Surge Barrier}
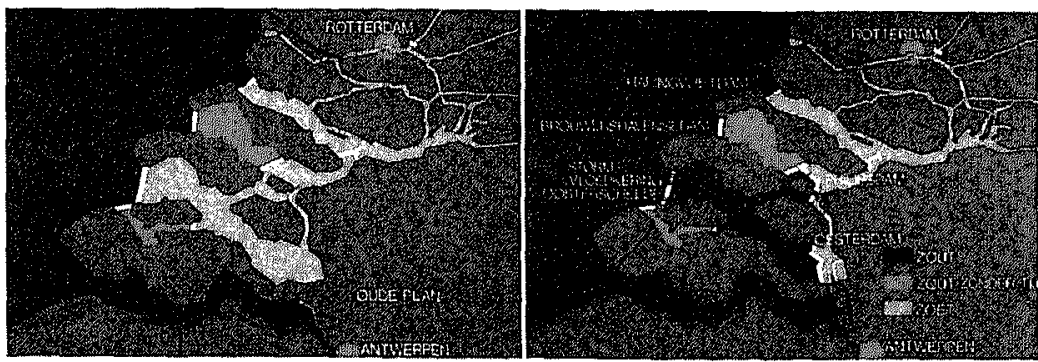

ESSAYS

FIG. 4 Left: The Delta Plan, 1958. Right: the revised Delta Plan, 1976. (Courtesy Rijkswaterstaat Archief.)

contribution to the 1953 closures, and it played a crucial role in different stages of the Delta Plan. In physical models, dimensions are scaled down by factors of one hundred and four hundred, time is scaled up by a factor of forty, sand is scaled down by using finely ground Bakelite, and water remains water at a scale of one to one. ${ }^{27}$ The most complicated models, such as the Oosterschelde model, used a combination of salt and fresh water. For detailed studies of dikes and constructions, wind and wave flumes were used. The organization of this model research was as difficult and crucial as interpreting the scaling principles. Managing the relations between the Rijkswaterstaat, the Delft Hydraulics Laboratory, and the private construction firms was thus as much part of the Oosterschelde project as the weaving of mattresses or the design of the storm surge barrier.

A final plan was presented to the government and approved in June 1976 (fig. 4). Debate in parliament descended even to such details as the size of the door openings in the construction, the construction schedule, and the budgetary controls. If ever a technological system deserved the label "designed by committee," this was it. The core of the adopted solution was to build a permanent structure in the mouth of the Oosterschelde through which the tide would flow four times each day, and which could be closed completely in case of a large storm. The principles of this solution were in all details different from that which the parliament had approved in 1974, and even in 1976 most of the research and design work remained to be done. The engineers of the Rijkswaterstaat and the construction companies worked in fully integrated teams toward this end. Next stages in the

27. Vertical downscaling, for example 100:1, cannot be as large as the horizontal downscaling, for example 400:1, because water's behavior changes fundamentally when flowing in more shallow streams. This is one example of the complicated principles of scaling involved in all technological modeling. Consequently, results from a model cannot be translated to full scale in any unambiguous or "objective" way, just as the results of scientific experiments cannot be taken to provide unambiguous answers about the state of Nature. 


\section{TECHNOLOGY AND CULTURE}

design process were discussed in parliament as late as 1977. Outside parliament, some crucial decisions-concerning, for example, the use of caissons or pillars-were made even later. One key decision was not to use caissons with integrated sliding doors but rather to hang the sliding doors between concrete pillars. ${ }^{28}$ These pillars, which numbered more than sixty, were of

JULY

2002

VOL. 43 cathedral-like dimensions: some 35 meters high, weighing 18,000 tons. They were built in dry dock and moved to their final positions by a specially built vessel. This mode of transport was made possible by the pillars' buoyancy; they were built with hollow interiors, which were filled with sand once the pillars were positioned. The accuracy of the whole operation could be measured in centimeters.

In 1981-83 a series of further crises in the storm surge barrier project developed. Although technological and scientific uncertainties lay at the roots of these crises, they took the political shape of predicted budget overruns. Clashes between parliament and government resulted in political compromises-design changes to make the project cheaper combined with acceptance of larger budget overruns. In a rather desperate last budget cut, the minister of public works decided in 1984 to use one fewer pillar and one fewer sliding door ${ }^{29}$ The decision had undesirable ecological effects, but budgetary problems had taken priority by that time. On 4 October 1986 Queen Beatrix of the Netherlands officially opened the Oosterschelde Storm Surge Barrier (fig. 5). Since 1986 it has been used to counter storm surges about once a year. ${ }^{30}$ And the thing still works.

\section{Technology, Management, and Politics}

The Oosterschelde barrier plunged the Netherlands and Dutch water management into deep crisis. It generated a profound political conflict that left no level of society untouched and revealed an unprecedented mistrust in the central water authority, the Rijkswaterstaat, thereby temporarily eroding an important element in the institutional structure of water management in the Netherlands. It also presented hydrological engineers with a challenge they had no idea how to meet. Between 1974 and 1986 this changed the world radically, or so it seems. Protection against flooding

28. Frank Spaargaren, chair of the Rijkswaterstaat Project Bureau Afsluiting until 1979 , recalled how uncertainty about the special fluidity of the Oosterschelde seabed tipped the balance in this casc. Interview by author (with Rob Hagendijk), Garderen, 19 May 1998.

29. The pillar had already been built, and can still be seen standing in the dry dock, next to the visitors center-called Neeltje Jans after its location on the former island of the same name-on the barrier. Mountaineers now practice climbing on the walls of this dinosaur-like remnant of techno-optimism. See www.neeltjejans.nl for the visitors center.

30. For an evaluation of the first five years, see Rijkswaterstaat Directie Zeeland, Veilig Tij: Evaluatie van de Oosterschelde na 5 jaar stormvloedkering (The Hague, 1991). 
Bijker | The Oosterschelde Storm Surge Barrier

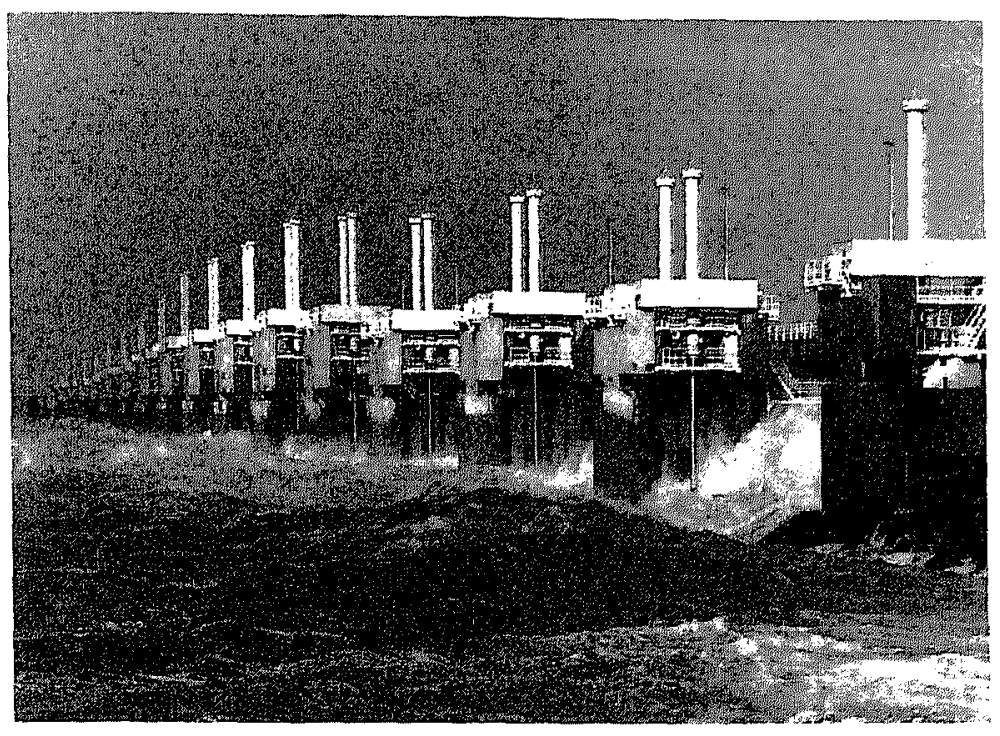

FIG. 5 The Oosterschelde Storm Surge Barrier. (Courtesy Rijkswaterstaat Directie Zeeland.)

came to be weighed against ecological concerns. The Oosterschelde was not closed, but defended with sliding doors. The Rijkswaterstaat lost its central role in Dutch society. The balance of power between state and private sector shifted, and a unique joint venture of the Rijkswaterstaat and private contractors took charge of the project. And, finally, the science and technology required were so innovative that even after the barrier was finished some engineers still could not believe it would really work. ${ }^{31}$

When we take a close look, however, we can see an argument to be made for continuity as well. Nobody questioned the basic safety goals of the Delta Law; ecological concerns were added to it. With the help of the 1972 Club of Rome report The Limits to Growth, which had a particularly significant impact in the Netherlands, ecological concerns could also be translated into safety terms, but on a larger scale. ${ }^{32}$ All parties involved, including the envi-

31. In the beginning the fact that the barrier worked had surprised some engineers who were particularly suspicious of the Oosterschelde seabed. Although they had given the exceptionally fluid sand special treatment and used extra foundation mattresses, they remained afraid that the pillars would shift and the sliding doors would jam. Now confidence has risen, and the barrier is generally expected to hold up for at least two centuries.

32. Donella H. Meadows et al., The Limits to Growth: A Report for the Club of Rome's Project on the Predicament of Mankind (New York, 1972). It sold more than two million copies all over the world, but the Dutch translation sold more than a hundred thousand copies in a single month. Maarten A. Hajer, The Politics of Environmental Discourse: Ecological Modernization and the Policy Process (Oxford, 1995). 


\section{TECHNOLOGY AND CULTURE}

ronmental action groups, were after solutions that could gain broad acceptance. And thus collaboration reemerged, not only between the Rijkswaterstaat and the building companies but also between the hydrological engineers and the ecologists. The Rijkswaterstaat recuperated after the slap in the face and regained control over the process, although for the contracting companies the Oosterschelde barrier remained one of the sweetest projects ever. Afterward its revival continued, and by the end of the last century the

vol. 43 agency had recovered its central institutional position in integrated water management. The hydrological science and technology deployed in the project were indeed radically innovative, but could only be developed from the basic techniques of previous centuries through the gradual learning process of the Delta school.

No surprise, then, that all involved-including the Rijkswaterstaat, the construction companies, environmental action groups, and politiciansare now happy with the barrier. Success has many fathers, and Dutch success even more so. 